\title{
Load bearing capacity of thin-walled rectangular and I-shaped steel sections of short both empty and concrete-filled columns
}

\author{
Amor Bouaricha \\ Department of Mechanical Engineering, Industrial Mechanical Laboratory. University of Badji Mokbtar, Annaba, Algeria \\ bouarichaa@yahoo.fr \\ Naoual Handel ${ }^{*}$ \\ Department of Civil Engineering, INFRARES Laboratory, University of Moubamed Cherif Messadia, Souk-Ahras, Algeria. \\ n.handel@univ-soukabras.dz,bttps://orcid.org/0000-0002-5711-9999
}

Aziza Boutouta

Mechanics Research Center (CRM), BP N73B, Constantine, Algeria.

boutoutariza@gmail.com

\author{
Sarah Djouimaa \\ Department of Civil Engineering, INFRARES Laboratory, University of Moubamed Cherif Messadia, Souk-Ahras, Algeria. \\ gc.djouimaa@yahoo.fr
}

\begin{abstract}
In this experimental work, strength results obtained on short columns subjected to concentric loads are presented. The specimens used in the tests have been made of cold-rolled, thin-walled steel. Twenty short columns of the same cross-section area and wall thickness have been tested as follows: 8 empty and 12 filled with ordinary concrete. In order to determine the column section geometry with the highest resistance, three different types of cross-sections have been compared: rectangular, I-shaped unreinforced and, reinforced with $100 \mathrm{~mm}$ spaced transversal links. The parameters studied are the specimen height and the cross-sectional steel geometry. The registered experimental results have been compared to the ultimate loads intended by Eurocode 3, for empty columns, and by Eurocode 4, for compound columns. These results showed that a concrete-filled composite column had improved strength compared to the empty case. Among the three crosssection types, it has been found that I-section reinforced is more resistant than the other two sections. Moreover, the load capacity and mode of failure have been influenced by the height of the column. Also, the EC3 and EC4 predictions were not conservative compared to the experimental strengths of the tested columns.
\end{abstract}

KEYWORDS. Load; Instability; Steel; mixed column; Cross-section.

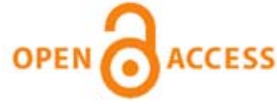

Citation: Bouaricha, A., Handel, N., Boutouta, A., Djouimaa, S., Load bearing capacity of thin-walled rectangular and Ishaped steel sections of short both empty and concrete-filled columns, Frattura ed Integrità Strutturale, 58 (2021) 77-85.

Received: 25.05 .2021

Accepted: 10.07 .2021

Published: 01.10.2021

Copyright: (C) 2021 This is an open access article under the terms of the CC-BY 4.0, which permits unrestricted use, distribution, and reproduction in any medium, provided the original author and source are credited. 


\section{INTRODUCTION}

$\mathrm{T}$ ubular steel columns filled with concrete have been widely used in structures around the world. They offer many mechanical advantages such as high ultimate strength, rigidity and high ductility at the same time. Several studies have been carried out on the hollow steel columns filled with different types of concrete under axial loads. The studied columns are made of thin-walled cold-rolled steel. These columns have a structure such that the majority of the soliciting load is supported by concrete, which is a very economical material that resists well to compression load. Thus, the cross-sectional components of this type of column result in significant economies in the design of buildings with different usages.

Several researchers have conducted recent experimental studies on the cross-sectional shape of thin-walled steel columns. The behavior and strength of concrete-filled aluminum tube columns using square and rectangular hollow sections under uniform axial compression have been analysed by Feng Zhou and al [1], It has been found that the shape of the crosssection, the thickness of the tube and concrete strength had a considerable effect on the local buckling of tubular columns.

Concrete-filled steel tubular columns (CFT) under axial and eccentric load, with and without binding bars were studied by Zhi-Liang Zuo and al $[2,3]$. They noted that the local buckling could be delayed by the installation of the binding bars. They have also noticed that decreasing the horizontal spacing of the bars increases ductility and strength. As per the study of Duarte and al [4], on the geometric effect of the cross-section of steel tubes with different grades and filled with rubber concrete (A.P.C), they concluded that the ductility increasing under axial load depended on the geometry of the crosssection, being more effective for columns with circular sections than those of columns with square or rectangular sections. Handel [5] studied the effect of age and type of filler concrete on the ultimate strength of six rectangular thin-walled coldrolled steel hollow tubes under axial loading. Three concrete mixtures have been used: ordinary concrete, slag concrete where the gravel and sand have substituted by crystallised slag and, slag sand concrete where dune sand has been substituted by crushed crystallised slag sand. The hollow tubes filled with slag concrete gave the best ultimate resistance. This was due to the high strength of slag concrete. It was also noted that, at the age of 180 days, the axial load capacity of mixed tubes filled with the three types of concrete, increased respectively by $13.98 \%, 3.71 \%$ and $3.10 \%$ compared to those found at 28 days age.

Weiwei Wang and al [6] studied eight T-shaped concrete-filled steel tubular (CFST) stub columns with stiffeners to high temperature under the compressive load. They have found that the temperature, thickness of steel tube, yield strength of steel tube and compressive strength of concrete are the key factors contributing to the axial compressive performance of the CFST stub columns and the failure pattern.

Nineteen lightweight aggregate concrete-filled steel tubular (CFST) columns with circular, square, square with roundended, rhombic, rectangular, rectangular with round-ended, elliptical, hexagonal asymmetric, T-shaped, pentagram, hexagon, octagon, 1/4 circular, semi-circular, D-shaped, fan-shaped, L-shaped and T-shape cross sections, have been tested under axial load by Ali Hameed Naser Almamoori and al [7]. All the CFST columns failed due to the crushing of the concrete core with local buckling of the steel tube. They noted that as the number of steel plates welded together to form the section increases, the section becomes more stable and leading to a better confinement. The columns with conventional cross-sectional shapes such as circle and square seem to have a relatively higher ductility index. But, as the shape becomes more irregular, the ductility index decreases.

A fully or partially encased composite column is a composite type column that consists of an H-shaped or I-shaped steel section with concrete poured between the opposing flanges. The advantage of this type of column is that it offers a simplified connection between beams and columns, with reduced formwork on two sides of the column.

Few researches has been conducted on profiles partially filled with concrete. Hunaiti and Fattah [8], Jamkhaneh and al. [9], Chicoine.T and al. [10], Begum and al. [11] studied the behavior and load-bearing capacity of a new type of composite column partially filled with ordinary concrete and thin-walled welded I-section reinforced with transverse links. The specimen's mode failure was local buckling with deformation of the steel at the flanges and crushing of the concrete. The studies showed the additional reinforcement could improve the column's ultimate load.

Handel and al [12] have noted that the increase in ultimate load capacity of thin-walled partially encased sections filled with slag concrete under axial loading attributed to the higher strength of the concrete. Also, it is confirmed that the length and thickness of the steel profile have a significant effect on the ultimate strength and failure mode.

Experimental and numerical results of a study of partially encased composite columns under concentric loads conducted by Margot F. Pereira and al. [13] indicated that the welded wire mesh could replace the transversal links between the flanges. 
According to the literature, there was a lack of experimental tests comparing concrete-filled tubular section columns and partially or fully encased profiles to understand which cross-section provided the best strength and stability performance. Therefore, an experimental study is performed on short thin-walled steel columns of rectangular cross-section, I-shaped without reinforcement and I-shaped reinforced by transverse links, under axial load, to analyze the ultimate strength and failure mode of these column types. The parameters studied are the height and the shape of the cross-section of the specimens. The recorded experimental results are compared with those given by the prediction of EC3 regulation [14] for empty steel columns and EC 4 [15] for mixed columns.

\section{EXPERIMENTAL PROGRAM}

\section{Geometric properties of specimens and their fabrication}

$\mathrm{I}$ $\mathrm{n}$ this work, a twenty short cold rolled galvanized steel columns with a thickness of $2 \mathrm{~mm}$ and a cross-sectional area $(100 \times 70) \mathrm{mm}^{2}$ are tested as follows: 8 empty and 12 filled with ordinary concrete, under uniaxial loading, to investigate the effect of column height and cross-section geometry on their load-bearing capacity and failure modes. The studied sections consist of two U-shaped cold-rolled steel obtained by cold bending and joined throughout the height by a continuous weld to form a hollow steel tube and welded back to back to forms an I-shaped steel section. Three types of cross-sections are compared: rectangular, unenforced I-shape and, I- stiffened by transverse links spaced by $100 \mathrm{~mm}$. The heights of the specimens are $200 \mathrm{~mm}-300 \mathrm{~mm}-400 \mathrm{~mm}-500 \mathrm{~mm}$. The test program contains 5 series of columns: - The first series represents empty steel specimens with an I-shaped cross-section (Fig. 1-a) designated as C1-C2-C3-C4; - The second series represent empty hollow rectangular section steel specimens (Fig. 1-d) designated as C5-C6-C7-C8; - The third series represents the partially encased I-shaped cross-sectional steel specimens (Fig. 1-b) designated as C9-C10C11-C12;

- The fourth series represents the steel I-shaped cross-section specimens partially encased and reinforced horizontally by round steel links of $3.3 \mathrm{~mm}$ diameter smooth in U-shape welded to the extremities of the flanges as shown in Fig. (1-c) designated as C13-C14-C15-C16. The transverse link spacing of $100 \mathrm{~mm}(\mathrm{~d}=100 \mathrm{~mm})$ has been used to increase the confined concrete capacity and to retard local buckling of the thin-walled steel;

- The fifth series represents hollow rectangular section specimens filled with ordinary concrete (Fig. 1-e) designated as C17-C18-C19-C20.
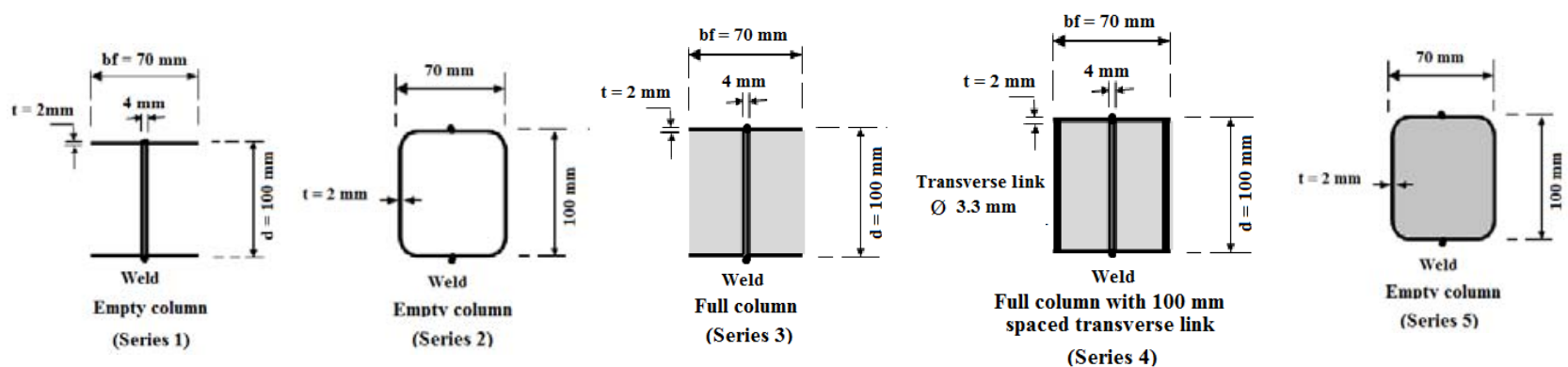

Figure 1: Cross section of test specimens.

\section{Steel}

The mechanical properties of the used steel for the short columns are:

- Young's modulus: $\mathrm{E}_{\mathrm{a}}=205000 \mathrm{MPa}$

- Yield strength: $\mathrm{f}_{\mathrm{y}}=300 \mathrm{MPa}$

\section{Concrete}

The method used to determine the filler concrete composition is that of the Gorisse-Dreux method. It is determined with maximum aggregate diameter $\mathrm{D}_{\max }=15 \mathrm{~mm}$ and a $6 \mathrm{~cm}$ slump (according to the NF P 18-451 standard) corresponding to a plastic concrete. The concrete composition is listed in Tab. 1. The short steel columns filled with ordinary concrete have been poured in a vertical position in three layers and vibrated on a vibrating table to obtain compact concrete throughout the specimen's height. The concrete compressive strength at 28 days is determined using the NF P 18-406 standard on three cubic specimens of dimension $(10 \times 10 \times 10 \mathrm{~cm})$, and the splitting tensile strength of the concrete is determined according to the NF P 18-408 standard on three cylindrical specimens of dimension $(16 \times 32 \mathrm{~cm})$. All casted columns 
hardened in a vertical position in laboratory ambient air (temperature $=20-25^{\circ} \mathrm{C}$ and relative humidity $=60$ at $70 \%$ ) (Fig. 2).

\begin{tabular}{ccccccccc}
\hline & $\begin{array}{c}\text { Cement } \\
\text { CPJ 42.5 }\end{array}$ & $\begin{array}{c}\text { Water- } \\
\text { Cement } \\
\text { Ratio } \\
\text { W/C }\end{array}$ & $\begin{array}{c}\text { Sand } \\
\text { Dune } \\
(0 / 2.5)\end{array}$ & $\begin{array}{c}\text { Limestone } \\
\text { gravel } \\
(5 / 15)\end{array}$ & $\begin{array}{c}\text { Real } \\
\text { density }\end{array}$ & slump & $\begin{array}{c}\text { Cubic compressive } \\
\text { strength of concrete } \\
\text { (28 days) }\end{array}$ & $\begin{array}{c}\text { Tensile strength of } \\
\text { concrete }(28 \text { days) }\end{array}$ \\
Unit & $\mathrm{Kg} / \mathrm{m}^{3}$ & - & $\mathrm{kg} / \mathrm{m}^{3}$ & $\mathrm{~kg} / \mathrm{m}^{3}$ & $\mathrm{~kg} / \mathrm{m}^{3}$ & $\mathrm{~mm}$ & $\mathrm{MPa}$ & $\mathrm{MPa}$ \\
Value & 350 & 0.60 & 811.32 & 1095.77 & 2.47 & 60 & 25 & 2 \\
\hline
\end{tabular}

Table 1: Compositions of the filling concrete.

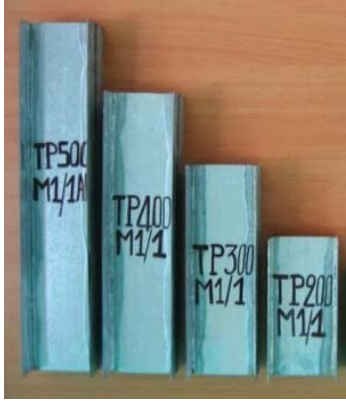

I-shaped empty

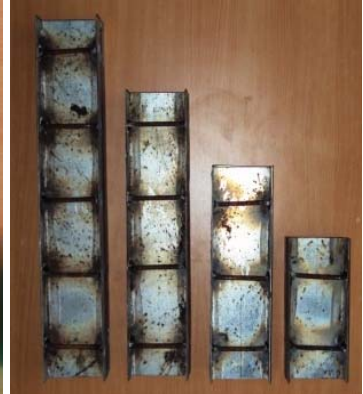

I-shaped empty with transversal links

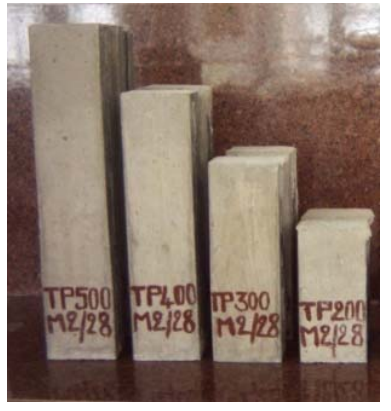

Concrete filled, I-form with and without links

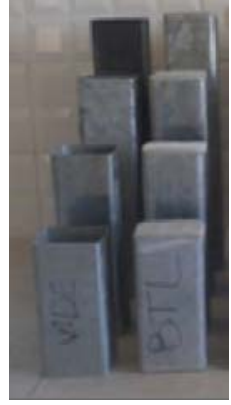

Empty and concrete filled, rectangular shape

Figure 2: A general view of the fabricated specimens.

\section{RESULTS AND DISCUSSION}

A 11 the specimens are tested to failure under axial compression at 28 days by a universal testing machine, with a capacity of $2000 \mathrm{kN}$. Particular attention is payed in checking the correct position of the columns before loading. The top and bottom faces of composite columns are treated to eliminate surface irregularities to provide a more uniform load distribution across the column cross-section.

Recorded experimental results are compared with those given by the prediction of EC3 regulation for empty steel columns and EC 4 for mixed columns. Experimental strength $\left(\mathrm{N}_{\mathrm{ue}}\right)$ of the specimens and their predicted strengths $\left(\mathrm{N}_{\mathrm{uc}}\right)$ according to EC3 and EC4 are presented in Tab. 2.

The ultimate load is examined under the effect of the geometry of the empty sections (I shape or rectangular) (Fig. 3): it is observed that empty specimens (C1, C2, C3 and C4) of the section I record an increase in load capacity of $(30.50 \%$, $40.66 \%, 47 \%$ and $52.75 \%$ ) respectively compared to the empty specimens (C5, C6, C7 and C8) of rectangular sections. In contrast, ultimate loads decrease for specimens $\mathrm{C} 4$ and $\mathrm{C} 8$ as heights increase. From these results, it can be concluded that the height of thin-walled cold rolled steel columns has a negative influence on the axial load capacity.

For the fourth series specimens (C13, C14, C15 and C16) of I-section partially encased and reinforced by horizontal links, it is recorded (see Fig. 4) an improvement of their load capacities respectively of the order of $40 \%, 45.35 \%, 52.52 \%$ and $61.37 \%$ compared to those of the non-reinforced specimens of the third series (C9, C10, C11 and C12). This improvement is not very important for their ultimate loads: it is respectively improved of $16.6 \%, 17.1 \%, 17.4 \%$ and 18 $\%$ comparing to the rectangular cross-section specimens of the fifth series (C17, C18, C19 and C20) (Fig.4).

These results also show the improvement of the load capacity in partially encased steel columns of ratio $(\mathrm{b} / \mathrm{t}=17.5)$ and reinforced with links. The ultimate load is inversely proportional to the height of the specimen.

Fig. 5 illustrates the ratio between experimental loads from the composite columns and the loads from the empty steel columns. The compressive strength of the filler concrete at 28 days is $25 \mathrm{MPa}$. Comparing the ultimate loads of the empty steel I-section specimens (first series) with those of the partially encased I-section specimens with no reinforcement (third series), it is noted that ultimate load increased from $34 \%$ to $69 \%$. The fourth series specimens with transverse links show 
an increase in ultimate load from $116.4 \%$ to $136 \%$. This reflects the advantage of short steel columns filled with concrete. More the transversal links welded at the butt of the footings and spaced $100 \mathrm{~mm}$ apart can improve the axial load capacity by $40 \%$ to $61.4 \%$ compared to the I-shaped section specimens not reinforced. Also, an increase of $130 \%$ to $153.4 \%$ for the ultimate loads of the 5 th series rectangular hollow concrete-filled specimens is observed compared to the empty ones (series 2). The concrete containment between the steel walls of the hollow section gives the highest load ratio.

\begin{tabular}{|c|c|c|c|c|c|}
\hline Test series & $\begin{array}{l}\text { Specimen } \\
\text { labels }\end{array}$ & $\begin{array}{l}\text { column } \\
\text { length } \\
(\mathrm{mm})\end{array}$ & $\begin{array}{l}\text { Width-to- } \\
\text { thickness } \\
\text { ratio: } \mathrm{b} / \mathrm{t}\end{array}$ & $\begin{array}{l}\text { Exp. ult. } \\
\text { strength } \\
\mathrm{N}_{\text {ue }}(\mathrm{kN})\end{array}$ & $\mathrm{N}_{\mathrm{ue}} / \mathrm{N}_{\mathrm{uc}}$ \\
\hline \multirow{4}{*}{$\begin{array}{l}\text { Series } 1 \\
\text { (Empty I- } \\
\text { section } \\
\text { columns) }\end{array}$} & C1 & 200 & 17.5 & 190.89 & 0.87 \\
\hline & $\mathrm{C} 2$ & 300 & 17.5 & 192.85 & 0.86 \\
\hline & $\mathrm{C} 3$ & 400 & 17.5 & 188.25 & 0.88 \\
\hline & $\mathrm{C} 4$ & 500 & 17.5 & 181.32 & 0.90 \\
\hline \multirow{4}{*}{$\begin{array}{l}\text { Series } 2 \\
\text { (Empty } \\
\text { rectangular } \\
\text { section } \\
\text { columns) }\end{array}$} & $\mathrm{C} 5$ & 200 & 17.5 & 146.30 & 0.61 \\
\hline & C6 & 300 & 17.5 & 137.10 & 0.57 \\
\hline & C7 & 400 & 17.5 & 128.00 & 0.54 \\
\hline & $\mathrm{C} 8$ & 500 & 17.5 & 118.70 & 0.50 \\
\hline \multirow{4}{*}{$\begin{array}{c}\text { Series } 3 \\
\text { (mixed I-section } \\
\text { columns) }\end{array}$} & $\mathrm{C} 9$ & 200 & 17.5 & 280.00 & 0.93 \\
\hline & C10 & 300 & 17.5 & 258.00 & 0.88 \\
\hline & C11 & 400 & 17.5 & 238.00 & 0.82 \\
\hline & C12 & 500 & 17.5 & 220.00 & 0.75 \\
\hline \multirow{4}{*}{$\begin{array}{c}\text { Series } 4 \\
\text { (mixed I-section } \\
\text { columns with } \\
\text { horizontal link) }\end{array}$} & C13 & 200 & 17.5 & 392.00 & 1.26 \\
\hline & C14 & 300 & 17.5 & 375.00 & 1.17 \\
\hline & C15 & 400 & 17.5 & 363.00 & 1.09 \\
\hline & C16 & 500 & 17.5 & 355.00 & 1.10 \\
\hline \multirow{4}{*}{$\begin{array}{l}\text { Series } 5 \\
\text { (mixed } \\
\text { rectangular } \\
\text { section } \\
\text { columns) }\end{array}$} & C17 & 200 & 17.5 & 336.11 & 1.02 \\
\hline & C18 & 300 & 17.5 & 320.00 & 0.97 \\
\hline & C19 & 400 & 17.5 & 309.10 & 0.94 \\
\hline & C20 & 500 & 17.5 & 300.84 & 0.91 \\
\hline
\end{tabular}

Table 2: Experimental results of empty steel and composite columns.

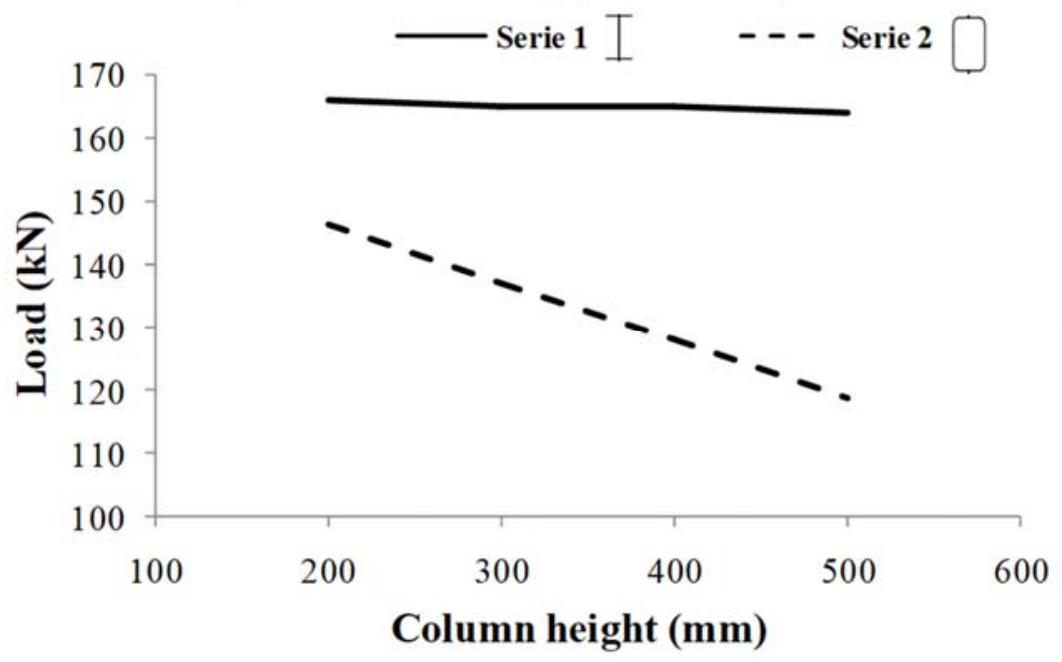

Figure 3: Experimental ultimate load $\left(\mathrm{N}_{\mathrm{ue}}\right)$ of empty steel columns. 


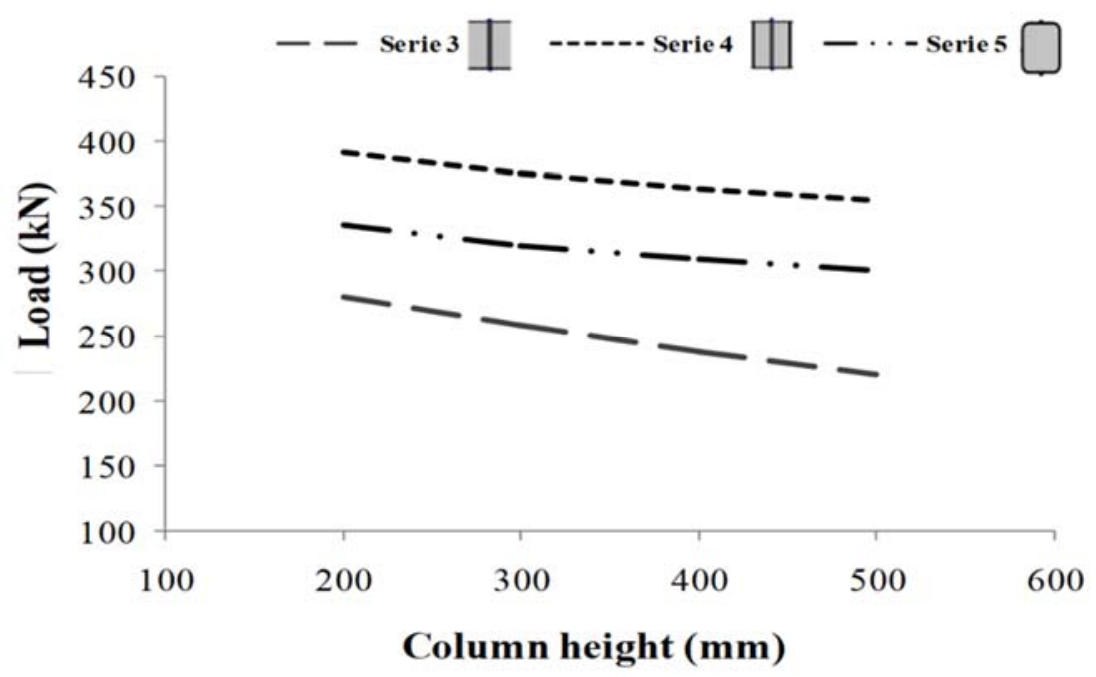

Figure 4: Experimental ultimate load $\left(\mathrm{N}_{\mathrm{ue}}\right)$ of composite columns.

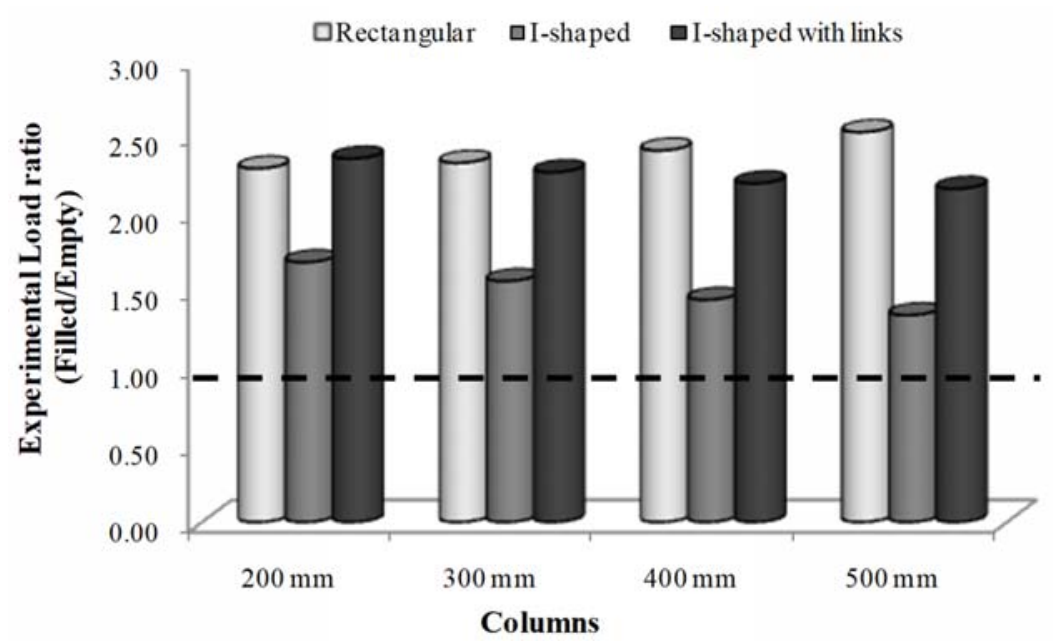

Figure 5: Strength gain for cross-section types.

According to EC4, the concrete contribution ratio (CCR) is the experimental ultimate load (Nue) divided by the yield strength (fy) of steel and the effective cross-sectional area that considers the local buckling of the steel tube (As.eff). Fig. 6 shows the CCR of the three composite column series. The results show that the I-shaped cross-section with horizontal links partially encased has a greater positive influence on concrete filling than the rectangular and I-shaped without horizontal links sections. That confirmed the tendency observed for the experimental ultimate load of the series 4 composite columns.

The experimental ultimate loads are compared to those given by the prediction of EC3 regulation for empty steel columns and EC 4 for mixed columns. The results presented in Fig. 7 showing clearly the experimentally obtained load capacity of empty steel columns is lower than predicted by EC3. Although short column experimental loads have expected to be close to those calculated according to EC3, the experimental results gave lower loads for empty columns due to premature buckling.

The error of predicting the axial capacity of the composite column is shown in Fig. 8. It can be observed that EC4 is not conservative where the error obtained with respect to the experimental load values varies from 0.93 to 0.75 . The same observation was noted for rectangular section specimens of heights of $500 \mathrm{~mm}, 400 \mathrm{~mm}$ and $300 \mathrm{~mm}$ with an error varying from 0.91 to 0.97 . But EC4 is conservative for rectangular section specimen of height $200 \mathrm{~mm}$. EC4 estimates safer predictions with an error varying from 1.10 to 1.17 for I-shaped specimens reinforced with horizontal links.

From the results of tests obtained on short thin-walled empty and concrete-filled cold-rolled steel columns under uniaxial loading, it should be noted that the instability of thin-walled local occurred at all specimens with low attenuation for composite columns, this is due to lateral stiffness contribution that prevents the specimens to produce large lateral 
displacements and therefore lesser the local buckling. Also, the length of the column has a significant effect on the local buckling. The typical failure modes for the tested partially encased columns are by fully or partial crushing of concrete, steel web end flange buckling outwards and inwards, with steel-concrete separation. The composite columns reinforced with transversal links of the 4th series have a more ductile mode of failure than the 3rd series columns. The horizontal links prevented concrete-steel separation, premature concrete cracking and minimized local buckling of the specimen flanges (Fig. 9).

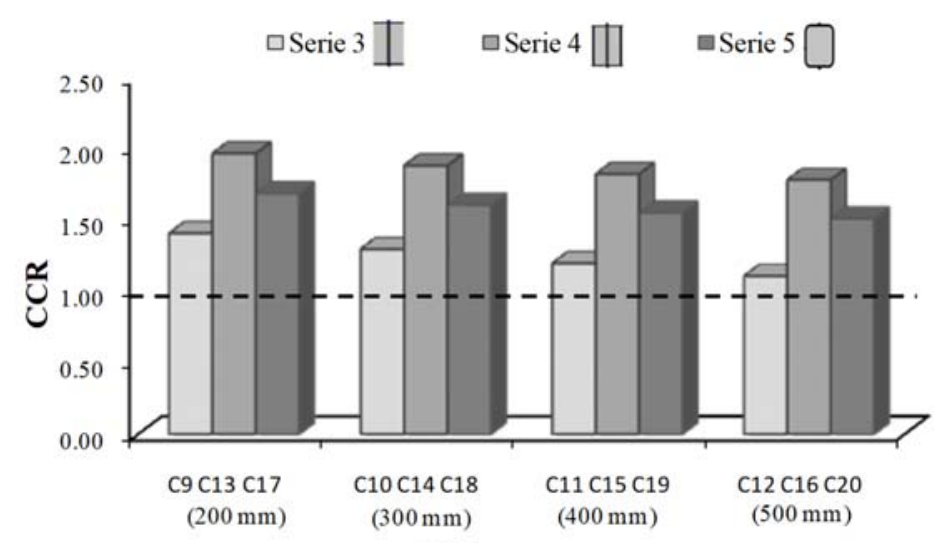

Columns

Figure 6: Concrete contribution ratio (CCR).

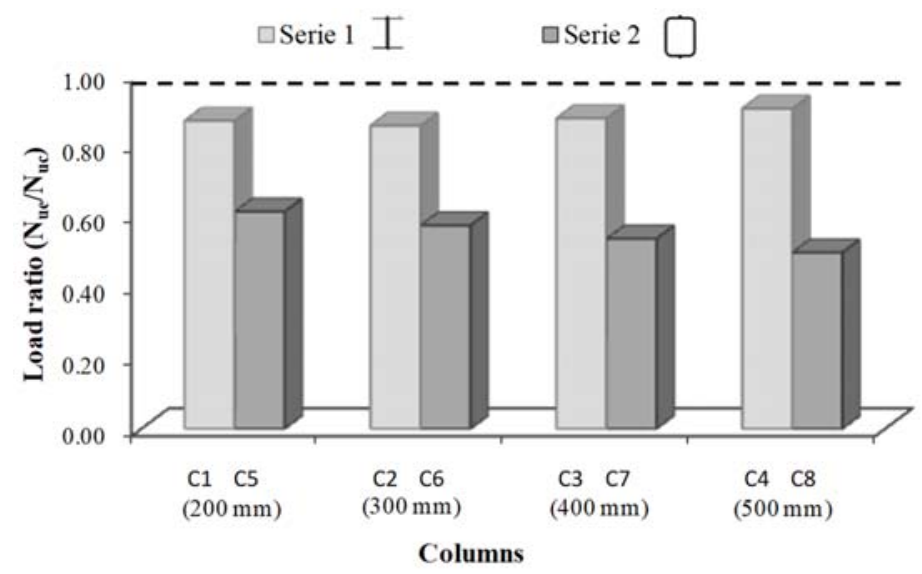

Figure 7: Empty columns load ratio $\left(\mathrm{N}_{\mathrm{ue}} / \mathrm{N}_{\mathrm{uc}}\right)$.

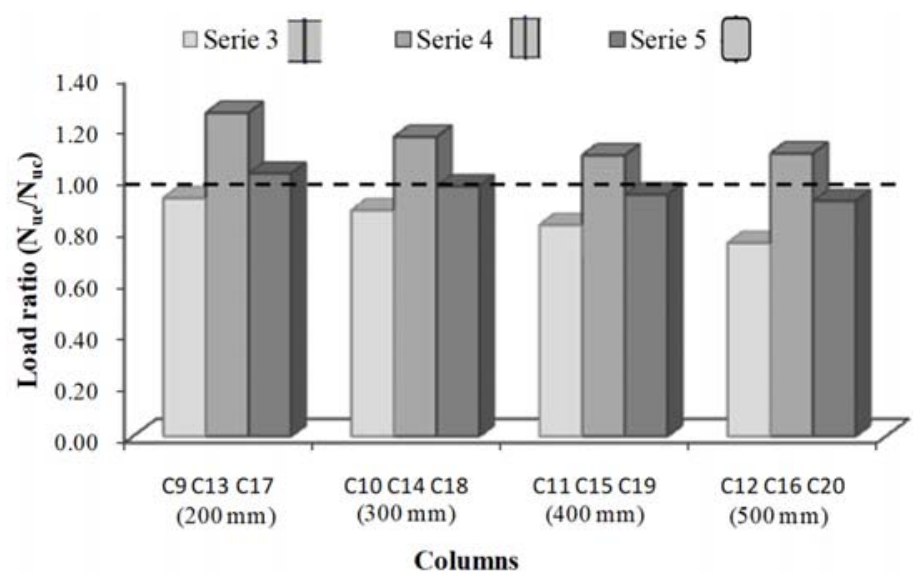

Figure 8: Composite columns load ratio $\left(\mathrm{N}_{\mathrm{ue}} / \mathrm{N}_{\mathrm{uc}}\right)$. 


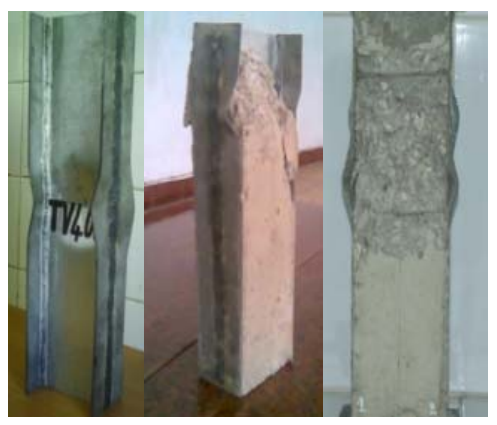

Empty Concrete filled I-shaped section

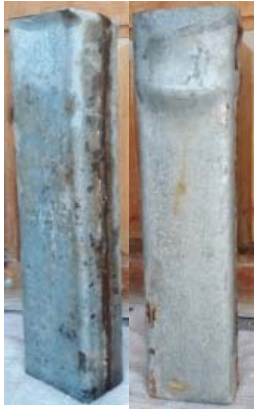

Empty Concrete filled

Rectangular section

Figure 9: Typical failure mode $400 \mathrm{~mm}$ high columns empty and filled with concrete).

\section{CONCLUSIONS}

his study has examined five series tests of cold-rolled, thin-walled short steel columns filled with ordinary concrete under uniaxial loading. From the experimental results of this study, some conclusions can be drawn:

- Increasing the column height (empty or composite) leads to a decrease in the ultimate strength for all types of studied cross-sections.

- The axial load capacity of composite columns filled with concrete is improved compared to empty columns.

- Transverse reinforcement of the I-shaped section with links improved the experimental ultimate loads of the composite column compared to the I-shaped without links section. Partial confinement increased strength gain by $49.81 \%$.

- The used column with I-shaped cross-sections and transversal links with a web thickness of $4 \mathrm{~mm}$, gave a higher experimental ultimate load than a rectangular section. This load has been influenced by the steel thickness. The strength gain is about $17.3 \%$ for all the heights of the specimens.

- All specimens failed by local buckling with the crushing of the entire or partially concrete. The local buckling becomes less significant as the height of the specimens increases.

- Multiple experimental tests are required to verify the validity of the EC3 and EC4 predictions for reconstructed crosssectional short columns of thin-walled cold-rolled steel under axial loading.

\section{REFERENCES}

[1] Feng, Z. and Ben, Y. (2008). Tests of concrete-filled aluminum stub columns, Thin-Walled Structures, 46(6), pp. 573583. DOI: $10.1016 / \mathrm{j}$. tws.2008.01.003.

[2] Zhi-Liang, Z., Jian, C., Chun, Y., Qing-Jun, C. and Gang, S. (2012). Axial load behavior of L-shaped CFT stub columns with binding bars, Engineering Structures, 37, pp. 88-98. DOI: 10.1016/j.engstruct.2011.12.042.

[3] Duarte, A.P.C., Silva, B.A., Silvestre, N., de Brito, J., Júlio, E. and Castro, J.M. (2016). Tests and design of short steel tubes filled with rubberised concrete, Engineering Structures, 112, pp. 274-286.

DOI: 10.1016/j.engstruct.2016.01.018.

[4] Handel, N. (2019). Experimental investigation of the blast furnace slag based Concretes filled in the thin walled steel stubs, International Review of Civil Engineering, 10(2), pp. 117-124. DOI: 10.15866/irece.v10i2.16418.

[5] Weiwei, W., Xuetao, L., Yuzhuo, Z., Yang, Y. and Tong, Z. (2020). Axial compression performance of thin-walled Tshaped concrete filled steel tubular columns under constant high temperature: Experimental and numerical study, Structures, 27, pp. 525-541. DOI: 10.1016/j.istruc.2020.06.004.

[6] Almamoori, A.H.N, Naser, F.H. and Dhahir, M.K. (2020). Effect of section shape on the behaviour of thin walled steel columns filled with light weight aggregate concrete: Experimental investigation, Case Studies in Construction Materials, 13, pp. 1-13. DOI: 10.1016/j.cscm.2020.e00356. 
[7] Hunaiti, Y. M. and Abdel Fattah, B. (1994). Design considerations of partially encased composite columns, Proc. Inst. Civ. Engrs Structs and Build., 106, pp. 75-82.

[8] Jamkhaneh, M.E., Kafi, M.A., \& Kheyroddin, A. (2018). Behavior of partially encased composite members under various load conditions: Experimental and analytical models, pp. 1-18. DOI: 10.1177/1369433218778725.

[9] Chicoine,T., Massicotte, M. and Tremblay, R. (2003). Long-Term Behavior and Strength of Partially Encased Composite Columns Made with Built-Up Steel Shapes, Journal of Structural Engineering, 129(2), pp. 141-150.

[10] Begum, M., Driver, R. G. and Elwi, E.A. (2007). Finite-Element Modeling of Partially Encased Composite Columns, Using the Dynamic Explicit Method, Journal of Structural Engineering, 133(3), pp. 326-334.

[11] Handel, N., Chikh, N.E and Achoura, D. (2009). Experimental investigation of partially encased composite column axially loaded», International Review of Mechanic Engineering, 3(6), pp. 825-832.

[12] Pereira, M., De Nardin, S. and de Cresce El Debs, A.L.H. (2016). Structural behavior of partially encased composite columns under axial loads, Steel and Composite Structures, 20(6), pp. 1305-1322. DOI: 10.12989/scs.2016.20.6.1305.

[13] CEN EN 1993-1-1. (2005). Eurocode 3: Design of steel structures - Part 1-1: General rules and rules for buildings.

[14] CEN EN 1994-1. (2004). Eurocode 4: Design of composite steel and concrete structures. Part 1-1: general rules and rules for buildings.

[15]Zeghiche, J. and Handel, N. (2007). Experimental behaviour of concrete filled thin welded steel stubs axially loaded case, 8th International Conference on Concrete Technology in Developing Countries, the African concrete code sympsium, Tunisia.

[16] Handel, N., Hafsi, B., Touati, A. and Djabbar, Y. (2011). Substitution of the aggregate by solid waste of blast furnance in the preparation of concrete, J. Mater. Environ. Sci, 2(1), pp. 520-525.

[17] Handel, N. and Madi, W. (2015). Experimental investigation of slag concrete-filled steel tubular columns axially loaded, 18th International Conference on Composite Structures (ICCS18), Portugal.

[18] Ye, Y., Han, L.H., Tao, Z. and Guo, S.L. (2016). Experimental behavior of concrete-filled steel tubular members under lateral shear loads, J. Constr. Steel Res, 122, pp. 226-237.

[19] Akchurin, T. K., Stefanenko, I. V. and Yurievna, P.O. (2017). Slag Wastes from Regional Metallurgical Industry Used in Construction Compositions, International Review of Civil Engineering, 8(5), pp. 197-202. DOI: $10.15866 /$ irece.v8i5.12681.

[20] Xiang, X.Y., Zhao, R.D. and Liu, Y. (2017). Calculation method of bearing capacity for self-compacting recycled concrete-filled steel-tube short column, Railw. Eng, pp. 34-37.

[21] Saleh, S.M. 2017. Size effect on the load carrying capacity of normal and lightweight concrete filled square steel tube composite columns, Int. J. Appl. Eng. Res, 12, pp. 5261-5266. 